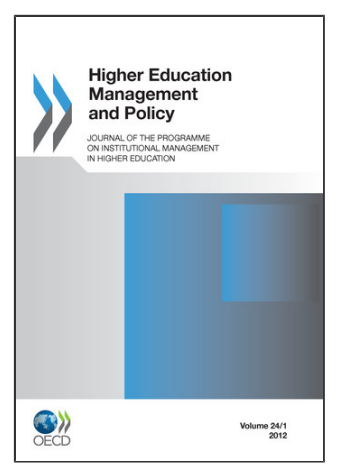

From:
Higher Education Management and Policy

Access the journal at:

http://dx.doi.org/10.1787/17269822

\title{
Institutional strategies in response to higher skills policy in England
}

\author{
Jim Hordern
}

Please cite this article as:

Hordern, Jim (2012), "Institutional strategies in response to higher skills policy in England", Higher Education Management and Policy, Vol. 24/1.

http://dx.doi.org/10.1787/hemp-24-5k9bdtj62zs3 
This document and any map included herein are without prejudice to the status of or sovereignty over any territory, to the delimitation of international frontiers and boundaries and to the name of any territory, city or area. 


\title{
Institutional strategies in response to higher skills policy in England
}

\author{
by \\ Jim Hordern \\ University of Bath, United Kingdom
}

Higher education institutions take strategic decisions regarding their engagement with government policy, with choice of strategy structured by the character of the national system and notions of what is appropriate in given contexts for the institution. In this study a series of factors influencing institutional strategy in response to the higher skills policy of the New Labour government in England during the period 2006-10 are briefly examined. How the policy was interpreted by institutions is discussed, in the context of the various forces that impact on strategic decision making at the institutional level, in addition to the influence of sectoral, regional and employer links. The significance of cultural change within institutions is highlighted, and the paper concludes with a suggestion as to why strategic engagement with this policy particularly suited certain institutions. 


\title{
Réponses institutionnelles à la politique du renforcement des niveaux de compétences en Angleterre : les stratégies mises en place
}

\author{
par \\ Jim Hordern \\ Université de Bath, Royaume-Uni
}

Les établissements d'enseignement supérieur adoptent des décisions stratégiques quant à leur participation à la politique gouvernementale, avec le choix d'une stratégie articulée autour de la spécificité du système national et des notions de ce qui est approprié dans des contextes donnés pour l'institution. Cette étude présente brièvement une série de facteurs influant sur la stratégie des établissements en réponse à la politique de renforcement des niveaux de compétences du gouvernement du Parti travailliste anglais au cours de la période 2006-10. Il est examiné comment la politique a été interprétée par les établissements, dans le cadre de divers facteurs qui influent sur la prise de décision stratégique au niveau institutionnel, et l'influence des liens avec les secteurs, régions et l'employeur. L'importance du changement culturel au sein des institutions est mise en lumière. L'article se termine par une suggestion indiquant pourquoi l'engagement stratégique avec cette politique a été particulièrement adapté pour certains établissements. 


\section{Introduction}

In national systems where publicly funded higher education institutions exercise a degree of autonomy from the state, institutional strategy can be influenced by factors relating to institutional mission, financial stability and demographic change, and structured both by the historical context of the national system and the institution itself, as well as the dynamics of the societal sector (Scott and Meyer, 1991) in which the institution operates. In some systems, for example in the United Kingdom, a complex relationship between higher education, the state and society, reliance on government funding, and the persistence of ideologies of "institutional autonomy" and "public service" structures institutional responses to government-sponsored initiatives (Kogan and Hanney, 2000; Stevens, 2004; Tapper and Salter, 1995). When faced with a new initiative or government policy, institutions may respond with various strategies, including enthusiastic or partial adoption, various modes of resistance or inaction. The extent to which each institution is able to contemplate different responses can depend on reputational position within the sector and the feasibility of maintaining financial stability if a policy is not adhered to, but may also reflect the attitude of institutional leadership towards risk, and the existence of viable alternative strategies.

This article explores a series of factors that influenced the strategic responses of higher education institutions to the higher skills initiative in England between 2006-10, a policy that emerged in response to the Leitch Review of Skills (HM Treasury, 2006), was outlined in the policy document "Higher Education at Work" (DIUS, 2008a) and involved the development of a series of funded workforce development projects at higher education institutions.

\section{"Appropriate" institutional strategies}

In their discussion of sociological institutionalism, DiMaggio and Powell (1991) stress the significance of taken-for-granted cognitive constructs in structuring decision making within professional environments. From this perspective, an interpretative discussion of strategy in higher education must seek to understand the socio-cultural influences which structure how decision makers conceive of possible futures for institutions. In an environment rich in tradition and held in high esteem by powerful groups within society, it is important not to underestimate the strength of notions of "appropriateness" 
(March and Olsen, 1984) which, in higher education, may vary with the differing contexts in which institutions are situated. It is likely that notions of appropriateness may also be actively contested within some institutions, as groups struggle for the dominance of their preferred conception of the appropriate means and ends of higher education. There are ongoing debates in national and international fora regarding the nature and purpose of higher education (Delanty, 2001) and this has been further accentuated in the United Kingdom in the current period of radical policy change.

Relations with government also impact on notions of appropriateness. Although institutional autonomy is characteristic of the UK system (Estermann et al., 2011; Tapper and Salter, 1995), the evolution of mass UK higher education has involved greater governmental activity and intervention (Kogan and Hanney, 2000; Stevens, 2004) including policy initiatives that encourage "private aspects of the public sector" (Kerr, 1990) acceptable to government, and new forms of control and dependence. These initiatives have been applied across a sector that contains institutions with varied origins such as public and private bodies and varied levels of resistance to external control (Kerr, 1990; Stevens, 2004), leading to a range of implementation outcomes at the institutional level. Furthermore, the degree of diversity and differentiation in the system, and the extent to which governments and institutions support further differentiation, impact on decision making at the institutional level (Vught, 2008). In such circumstances, interpretations of the policy context within institutions and in the wider higher education community have a powerful impact on notions of what is strategically appropriate. The interplay between conceptions of appropriateness at the institutional level, and the forces of academia, government, the market and societal objectives (Becher and Kogan, 1992; Clark, 1983; Kogan and Marton, 2006, p. 73) therefore provide a lens through which institutional strategy can be understood.

DiMaggio and Powell (1983) also argue that, in conditions of ambiguity and lack of clarity over the relationship between means and ends, organisations will tend to model themselves on those organisations within the field or sector that are considered successful, resulting in isomorphic trends. This standardisation of institutional form is likely to increase standardisation of aspiration within the sector or field, with institutions referencing the activity of others considered comparators or competitors. Decisions relating to government policy may also be guided by peer activity and the perception within an institution that there is an imperative to adapt to the changing environment in order to maintain institutional position (Vught, 2008), leading potentially to isomorphism at a peer group level. These isomorphic pressures interact with innovations at the institutional level (Stensaker and Norgard, 2001) as institutions attempt to reconcile external sectoral pressures with imperatives to make internal change coherent. In higher education sectors 
there are often powerful concepts of what a "university" is or should be, with commitments to notions of disinterested truth seeking and individual academic autonomy, values and stewardship (Watson, 2007; Stevens, 2004), in addition to "entrepreneurial" models that are aligned with a discourse that views the university as increasingly embedded in a web of industrial knowledge co-production (Bleiklie and Kogan, 2007; Gibbons et al., 1994). These concepts also share the higher education landscape with the traditions of professional development for "higher vocations" (Delanty, 2001) and a broader pragmatic "vocationalism", which for most of the 20th century in England was primarily associated with the technical institutes, technological universities and the polytechnics (Burgess and Pratt, 1970; Pratt, 1997; Pratt and Burgess, 1974).

Since the 1980s a politically driven vocationalism, often described as a "new vocationalism" (Symes and McIntyre, 2000; Grubb and Lazerson, 2004), has gained strength in the United Kingdom. This has influenced understandings of the vocational mission of the former polytechnics, many of which have also been subject to the influence of "academic drift" (Pratt, 1997; Pratt and Burgess, 1974) which can be perceived as a response both to government activity and part of a tendency towards institutional isomorphism within the sector. Governments have often lent the new vocationalism a strongly instrumentalist invigoration, which can obscure some of the complexities of the notions of vocation, professionalism and the relationship between disciplinary knowledge and more "practical" knowledge arising outside established structures (Bernstein, 1999). These vocationalist strands co-exist with aspects of "comprehensiveness" (Larsen and Langfeldt, 2005; Kingston University, 2008) which, in the case of the former polytechnics, has echoes of the "service tradition" of higher education (Pratt, 1997). The blending of a vocationalist commitment to preparedness for work and a comprehensive commitment to increased levels of participation in higher education for the good of the economy and society permeated New Labour government thinking from 1997 onwards (Stedward, 2003), reflecting the alignment of the forces of government, society and the market in ways that were acceptable to notions of appropriateness in those institutions with vocational and service traditions.

\section{The higher skills agenda}

Elements of the new vocationalism can be seen in the recommendations for higher education set out in response to the Leitch Review, commissioned by the UK government in order to propose change to skills policy (DIUS, 2007; HM Treasury, 2006) and "Higher Education at Work" (DIUS, 2008a), documents which assert that increases in skills levels are the key priority in ensuring future national competitiveness. The Leitch report states that "skills is the most important lever within our control to create wealth" and that "institutional 
change and simplification are necessary" (HM Treasury, 2006, p. 7) to bring this about. The government's implementation plan pledged a "demand-led approach" that expects "the colleges, universities and training providers that supply education and training to be increasingly responsive to what learners and employers actually want" (DIUS, 2007, p. 10). It also set a number of qualification-related targets, including ensuring that "more than 40 per cent of all adults have a higher education qualification" by 2020 (DIUS, 2007, p. 12). However, the logic of this approach has been substantially undermined by research that has questioned the priority status given to supply-side reform in driving economic productivity (Keep, 2008), the reductive equating of "skills" with "qualifications" that pervades policy rhetoric (Davis, 2007) and the assumed dividend accruing to individual investment in higher education in the context of globalisation (Brown, 2003; Brown et al., 2010). The United Kingdom Commission for Employment and Skills, an organisation which arose as a consequence of a recommendation of the Leitch Review in an attempt to "depoliticise" the skills agenda (HM Treasury, 2006), has suggested that productivity increases are not possible without changes in employer practices simultaneous to provider reform (UKCES, 2009), an argument that is subtly different from the unilateral focus on supply-side changes to bring about greater employer involvement in the specification of educational provision set out in the Leitch Review. In terms of higher education, the case for a "culture shift" (DIUS, 2008a, p. 4) so that institutions deliver "the higher level skills that a particular business needs in a particular sector in a particular place" (id., p. 7) is absent from the policy rhetoric of the new UK coalition government, in an environment subject to substantial funding uncertainties and political and economic change.

Craig and Gunn (2010) discuss the strategies that higher education institutions could potentially adopt in the face of the fragmentation of assumptions underlying the knowledge economy, upon which much recent industrial policy in the United Kingdom has been constructed. The three approaches they identify include decoupling institutional strategy from overtly economic imperatives, an internationalisation strategy that could mirror the "offshoring" which they perceive is occurring within the global economy and, finally, the potential for even greater emphasis on alignment with perceived industrial skills needs so as to ensure that the national economy is as well placed as possible to compete on the global stage. Craig and Gunn (2010) identify the higher skills strategy of the United Kingdom government over the recent period as a vehicle through which the final option could be enacted. Indeed, the existence of considerable "capacity building" funding (over GBP 100 million) made available by the Higher Education Funding Council for England (HEFCE) over the period 2006-10 to enable greater numbers of those in work to gain a higher education qualification appears to 
have been designed as an opportunity for institutions to re-orientate their educational provision and structural capital (Garnett et al., 2008), including their internal processes and institutional infrastructure, towards the emerging agenda. It is also an attempt to draw higher education institutions into supporting the Leitch objective of ensuring that $40 \%$ of the adult population have a higher education qualification by 2020 (HM Treasury, 2006).

In the remainder of this article we briefly examine five key strategic questions that have influenced institutional responses to this policy. The discussion is based on an analysis of relevant policy documentation, responses to the Higher Education Business Community Interaction Survey (HEBCI-S), the oral and written proceedings of the Innovation Universities Science and Skills (IUSS) Select Committee inquiry into the implementation of the Leitch recommendations, and a series of semi-structured interviews carried out during 2009-10 with a small sample of managers of workforce development (WD) projects funded under this initiative.

\section{Is this a policy for our institution?}

Policy initiatives that contain an implicit expectation that all higher education institutions will participate, for example, the widening participation or access policies in England, and those where engagement may be more appropriate for institutions of a certain type, are likely to engender differing institutional responses (Brennan and Little, 2006). In relation to higher skills policy, it appears the latter was the case. Institutions were encouraged to submit proposals for WD project funds (HEFCE, 2006) and, of proposals that proceeded, the majority were from post-92 institutions, including former polytechnics and colleges of further and higher education. Certain institutions may feel it is part of their duty to respond positively to a government policy, in a spirit of public service. This attitude is epitomised by the "public duty" commitments reported from some vice-chancellors (Frean, 2008), reflecting an enduring aspect of the "service tradition" of the polytechnics (Pratt, 1997). It is perhaps also demonstrated in the comments made by the then Chief Executive of HEFCE, Professor Eastwood, to the "After Leitch: Implementing Skills and Training Policies" Select Committee inquiry, which include the suggestion that institutions "will deliver the priority of the day" (Eastwood, 2008). In contrast, at a similar time, the Vice-Chancellor of Cambridge, Alison Richard, was openly critical of government attempts to use higher education as a vehicle for the government's policy objectives (Shephard, 2008).

Strategically, it is clear that research-intensive institutions have greater opportunities to choose which elements of government policy to satisfy. Many of these institutions are engaged in research partnerships with industry, 
which can be perceived as meeting the objectives of the Innovation Nation White Paper (DIUS, 2008b), and may prefer initially to extend this activity rather than engage in upskilling those currently in work who have not had access to higher education previously. In 2005-06, the majority of the United Kingdom's top 20 institutions in terms of income generation from continuing professional development (CPD) and continuing education were research intensive pre-92 universities (CBI/UUK/HEFCE, 2008), often delivering CPD through durable linkages with professional bodies or large employers. These institutions can therefore claim that they are already engaged in development of the national workforce, albeit usually at a postgraduate professional level. On the other hand, institutions with weaker research infrastructure may have limited scope to extend industrial research partnerships into areas of CPD. They may feel under greater pressure from the government to further develop provision for those in work at undergraduate level in accordance with their "culture, strengths and mission" (Wedgewood, 2008) and to work particularly with industries with lower qualification profiles. Decision makers in institutions are also likely to be sensitive to how a new initiative will be perceived internally, with regard to the cultural norms that pervade the institution, levels of confidence or "belief" in institutional leaders and the institution itself (Tierney, 1988) and the mode and pace of internal change or cultural re-orientation.

\section{Is this the most appropriate strategy for our financial and market position?}

Experimenting with new forms of employer demand-led higher education carries reputational and financial risk. This point is made by both Universities UK, who stated that employers must "share the cost and risk where student demand is untested" (Universities UK, 2008a) and Million+, the think-tank primarily associated with some of the former polytechnics, who noted that "the cost to institutions of work-based provision are often underestimated" (Million+, 2008). This was also acknowledged by the Department for Innovation, Universities and Skills with regard to higher skills activity, in stressing the imposition of "significant upfront risks and costs on an institution" in the creation of a new programme, particularly where there is a "risk of being unable to recoup the costs from the fees employers are prepared to pay" (DIUS, 2008a, p. 26). Engaging employers in the design, development and delivery of educational provision for their staff and then accrediting this as higher education may also be anathema to some academic staff, indicating that investment in institutional capacity may be necessary to ensure the requisite skills and knowledge are readily available.

Higher education for those in work is heralded as a new source of recruitment, which would serve to mitigate the impact of demographic 
changes on higher education institutions and meet the need to re-skill or upskill the existing workforce (CBI/UUK/HEFCE, 2008; HM Treasury, 2006; Sastry and Bekhradnia, 2007; Universities UK, 2008b). This non-traditional form of higher education "is seen by some institutions as vital to ensuring their financial viability and sustainable growth" (CBI/UUK/HEFCE, 2008). However, implementing processes to develop such provision at an institutional level entails up-front capacity building and programme design costs, in addition to tapping an uncertain level of demand. Those institutions unused to active recruitment within non-traditional markets may see this type of activity as an unnecessary risk, which they have neither the appetite nor the experience to undertake. Furthermore, such institutions may prefer to concentrate on increasing international recruitment, a potentially more lucrative and prestigious strategy, although it also carries significant risks (Bone, 2008; Vickers and Bekhradnia, 2007).

Non-engagement in higher skills policy is a plausible course of action for many institutions, if the risks are deemed too great or the cost of foregoing alternative strategies considered too high. Concern regarding rankings, league tables and measures of performance may also result in non-engagement, particularly for those institutions in a strong position relative to competitors. However, it is also plausible that institutions are prepared to contemplate engaging in multiple initiatives and strategies to reduce longer-term risk, particularly in an increasingly uncertain environment where strategies are not necessarily mutually exclusive. A "multiversity" (Kerr, 2001) may see such an approach as entirely appropriate, husbanding a variety of operations offering distinctive services to different markets while maintaining core traditional research and teaching activities. Those institutions less concerned about their association with traditional or elite higher education may view engagement positively, particularly given the offer of up-front capacity building funds to cover much of the initial outlay (HEFCE, 2006).

There were 34 HEFCE-funded workforce development (WD) projects in March 2009 (HEFCE, 2009). Of these, 7 were based at pre-92 institutions, with 23 based in post-92 universities and the remaining 3 either consortia collaborations or based at a university college. The 7 pre-92 institutions included 3 former Colleges of Advanced Technology (CATs) located in industrial areas of the North and Midlands, with origins as technical colleges serving local populations, and therefore institutions that historically have a strong vocational aspect to their mission. Significant HEFCE-funded investment in supporting new types of provision for those in work may be attractive to these institutions as a means of maintaining steady growth and as an alternative to scenarios of increasingly intensive competition for local (or national) "traditional" students as a consequence of demographic change. A strategic decision to broaden revenue 
streams in the face of the perceived risks of over-reliance on one source of funding was demonstrated in an interview with a WD project manager.

It's about not being over-reliant on one source ... and I think we do have a disproportionately high international student population ... but that can make the institution vulnerable if something happens overseas that's outside of our control ... there are clearly opportunities there but it's not a good idea to be overly dependent on that. (Interviewee 1)

At an institution with fewer international students, a WD project manager spoke of the need for the institution to have a broader range of revenue options, with "most universities working on international recruitment and increasing full-time undergraduates ... we are so pleased we got this from the HEFCE workforce development fund". However, the strategic importance of the initiative should not be over-emphasised, as the interviewee went on to say "I don't think it's going to be one of the principal areas for the university." (Interviewee 3)

Opportunities for business development through employer engagement are clearly recognised, as demonstrated by explicit objectives to build "longer term relationships ... that might offer opportunities for research, knowledge transfer, IP exploitation, use of facilities and resources in ways that are mutually beneficial", although "there are not always a lot of incentives for employers to invest in HE” (Interviewee 2). Entrepreneurialism may also accentuate competition with other institutions locally, resulting in tensions if institutions are simultaneously trying to collaborate as part of a wider skills or economic development initiative and compete for traditional undergraduates. An example of such a development was outlined by Interviewee 2, who spoke of organising an event to support awareness of higher education at an employer-facing government agency. This would involve "bringing other HEIs on board" who are "competitors as well so we have to manage that".

As institutions increasingly place a greater emphasis on (re)engagement with employers and enter markets previously dominated by training providers, the field of competitors could broaden, with a concomitant necessity to analyse potential markets in greater detail, in addition to more sophisticated relationship management. In some cases there may be moves towards partnering with training providers with an acknowledgement that higher education institutions can benefit from a co-operative arrangement. In the words of one institutional project manager, "instead of competing with a training provider we'll work with you and accredit what you're delivering" (Interviewee 3), in this case offering institutional quality assurance as added value to the provision offered. 


\section{Do we have relevant sectoral, local and regional links?}

The government intended that institutions deliver "the higher level skills that a particular business needs in a particular sector in a particular place" (DIUS, 2008a, p. 7). There is strong evidence that institutional strategy regarding new and potentially risky provision is usually focused on key sectors which institutions believe they have the structural capacity to provide for, based on their existing departmental or research capabilities. Institutions claim that "key strategic themes" at an institutional level are "aligned to key sectors" and workforce development activity "naturally reflects the strengths of the institution" (Interviewee 2). This process of alignment may be partly a result of rebalancing the portfolio of institutional activity towards less risky sectors, within the constraints of institutional infrastructure.

The Higher Education Business Community Interaction (HEBCI) survey 2006/07 was undertaken at a similar time to the circulation of the letter which announced the availability of funding for workforce development projects (HEFCE, 2006). Data from the survey would seem to indicate that the notion of sectoral engagement has salience, although engagement with a large proportion of the sector skills councils (the bodies charged with representing employers across industrial sectors) appears to be weak. For example, 105 institutions were involved with the construction sector and yet only 52 had engaged with Construction Skills, the relevant sector skills council, and 114 institutions were involved in financial services sectoral work and yet only 39 had engaged with the Financial Services Skills Council (HEFCE, 2008). Over 100 institutions engage with some of the largest industrial sectors of the economy (i.e. education, health, public administration, manufacturing and financial services) (id.) and these are primarily sectors with established patterns of recruiting graduates and working in partnership with higher education.

Question 3 of the HEBCI survey, which asks how institutions determine which sectors they work with, indicates that 93 institutions took their cue from the priorities outlined in government-influenced regional strategies, but this is lower than those responses which suggest that decisions are taken with reference to "best fit" with strategy (137), direct response to demand from companies (122), or the identification of business clusters by the institution (96). In response to question 6 , which asks institutions which geographical unit has most relevance to the institutional mission, only 51 institutions consider the region, for example the South West or Yorkshire and Humber, to be a priority, with a higher proportion (79/160) preferring an area defined by the institution (HEFCE, 2008).

The erosion of linkages between local and regional bodies which arose as a result of incorporation and the removal of the polytechnics and colleges from local control in 1988 with the Education Reform Act, followed by the 
ending of the binary line between universities and polytechnics in 1992, has enabled a situation to develop where institutional strategy need not be bound by any local or regional concerns (Pratt, 1997; Stevens, 2004). As a result, many institutions may have taken strategic decisions regarding infrastructure, investment and recruitment over the last 15 years that may not necessarily have accorded with the economic interests of their region or local area. On the other hand, the liberation from local control could have allowed some institutions to be at the forefront of the diversification of the industrial base of their local areas, both proactively producing knowledge and reacting to the specific needs of individual employers in an organic fashion. However, longterm dependence on government funding may have reduced the likelihood of this happening. Low investment in expensive institutional infrastructure, for example in the sciences or engineering, which may have come about as a result of strategic institutional responses to the policy context and financial realities, is difficult to reverse quickly and thus may reduce the capacity of institutions to respond effectively to certain local employers.

\section{How can we make best use of our existing links with employers?}

Those institutions with strong links with employers, whether through current workforce development, student placements, research or knowledge transfer, can chose to invest time and resources into sustaining, deepening and broadening those links. All institutions will have links with employers, but in many cases these relationships may be one-dimensional, i.e. focused only on one aspect of university activity. However, developing and managing relationships with employers requires resources and consideration of how this "third space" function interrelates with what are often termed the core academic activities of teaching and research (Bolden and Petrov, 2008). At least 11 institutions funded through HEFCE workforce development projects have moved towards "front desk" operations that seek to provide a relationship management service and a first point of contact for employers (HEFCE, 2009) across all spheres of university activity. However, an effective front desk relies on supportive institutional processes or "structural capital" (Garnett et al., 2008, Voorhees and Harvey, 2005); otherwise commitments to employers may not be realised.

One WD project manager emphasised the necessity for "dialogue with research and knowledge transfer within the institution, ... how the website works in terms of the front face and how employers navigate through the website, but also how we work as people, how we communicate the totality of the university's offer" (Interviewee 1). This notion of corporate communication, promoting the "offer" to prospective clients through a corporate identity, may run counter to the cultural dynamic prevalent in particular institutions and thus prove problematic to implement (Tierney, 1988). The project manager 
identified "variation in practice across the university" and considered "getting more consistency across the piece and developing what characterises a (University Name) experience" (Interviewee 1) a strategic institutional objective. Such an approach, while streamlining the processes necessary for managing employer and student engagement, might result in a loss of flexibility and initiative at the individual level.

\section{How can we maximise the entrepreneurial culture? Is this desirable?}

A contrasting, and perhaps more challenging, approach that institutions might prioritise is that of rewarding or recruiting academic staff on the basis of their entrepreneurial qualities. The strategy here would be to more explicitly encourage academic staff to devote greater amounts of time to developing more profitable links with employers. Relying on entrepreneurialism may suit those academic staff who are already entrepreneurial, in that they may be able to retain control of their existing relationship with the employer in question, although it may also result in increased resistance if the approach includes any stipulations as to how this work should be carried out. However, the notion of the "entrepreneurial university" also encounters more general resistance. As suggested by Timlin et al. (2010), Garnett et al. (2008) and the relevant HEFCE, HEA and government documents (HEA, 2008; HEFCE, 2006; DIUS 2008a), the realisation of the objectives of higher skills policy are just as much about cultural change as the availability of funding or the delivery of appropriate activity. "Higher Education at Work" draws attention to the potential of a culture clash between employers and institutions on the basis that "the cultures and norms in the different sectors are different" (DIUS, 2008a, p. 27), a recognition of the salience of perspectives that view greater industrial involvement as a threat to academic freedom and the pursuit of knowledge for its own sake (Delanty, 2001; Giroux, 2003).

There is some evidence of internal culture change proving problematic, in the context of the persistence of what is termed a "traditional ... content or knowledge-based view of HE" (Interviewee 1), and resistance to the premise set out by Gibbons et al. (1994) that the relationship between knowledge, research and education has changed irrevocably. Amongst higher skills enthusiasts, traditional higher education is sometimes criticised for its topdown "transfer of knowledge base from expert to student" (Interviewee 1), without acknowledgement of the role of the student in contributing to disciplinary knowledge (Delanty, 2001). This can be presented in opposition to what is often portrayed as the "virtuous" and more democratic approach of "acknowledging that there is expertise in the workplace" (Interviewee 1). The acceptance that there is tension around culture change and the nature of higher education is evident in the suggestion by a workforce development 
manager that the funded projects are partly about "exploring those different views of what HE is ... and how it can transform individuals and workforces" (Interviewee 1). Strategies aiming to entrepreneurialise the culture within institutions may also fall victim to persistent disconnect between centrally driven initiatives and the rest of the staff (McNay, 2005), or even accentuate fragmenting relations within the institutional community.

Without considerable institutional commitment and a resolution amongst senior staff to recognise employer engagement activity as a valued part of the academic role there are likely to be constraints on the evolution of workforce development activity. The 2006 version of the Higher Education Academy's Professional Standards Framework (HEA, 2006) made no explicit mention of a need for employer engagement skills or the professionalism needed to negotiate learning and programme outcomes with third parties. A workforce development project manager involved in trying to engage academic staff in greater levels of workforce development activity observed that "there is a real need for staff development in this area" suggesting the possibility of "embedding it in our Postgraduate Certificate" and delivering "a more detailed in-depth suite of programmes around work-based learning, quality assurance, assessment" (Interviewee 2). Equally important, from the point of view of increasing staff interest in developing greater skills in this area, are the criteria by which staff are recognised in terms of promotion to more senior academic positions. Timlin et al. (2009) identified 48 institutions planning to make investments in professional development for staff in this area, but also perceived a sector-wide lack of awareness amongst staff of the skills required for effective employer engagement.

\section{Conclusion}

Institutional strategy is constrained by the context in which institutions exist and operate, disciplinary profile, infrastructure and structural capital (Garnett et al., 2008; Voorhees and Harvey, 2005), in addition to some of the contrasting conceptions of higher education that form notions of appropriateness within the sector. It is noticeable that many of the funded WD projects aimed to address issues of culture and institutional processes (HEFCE, 2009), but these projects were also hosted at institutions where one could reasonably expect the persistence of a public service ethos as an institutional norm. The projects can be seen as evidence of the belief that higher education institutions have a continuing role in participating in the policy initiatives of the state, particularly where these can, at least in appearance, cohere with welfarism and beliefs in social justice. Indeed, higher skills policy and the WD projects of 2006-10 can be seen to have the significant advantage of addressing three of the forces in Becher and Kogan's (1992) adaptation of Clark's triangle, those of government, the market and welfarism, in addition to supporting the possible expansion of 
new modes of provision. Both the policy and the projects therefore proved particularly attractive to post-92 universities and one part of the pre-92 sector, and this may have made for greater acceptance across institutions.

Furthermore, with the increasing dominance of the "multiversity" model (Kerr, 2001), institutions can be perceived as fragmented sets of business units pursuing specific objectives with devolved budgets, cultures and practices held together by a strategic managerialist core (Bleiklie and Kogan, 2007; Deem et al., 2007). This enables disparate activity to co-exist simultaneously, which is particularly useful if there are "traditionalist" reservations. However, with a new UK government intent on using different mechanisms to challenge the higher education system and less convinced of the need for a centrally driven skills policy, it appears that opportunities to "deliver the priority of the day" (Eastwood, 2008) in this policy area may be harder to find over the next period.

The author:

Jim Hordern

Part Time Teaching Fellow

Division for Lifelong Learning

University of Bath - Claverton Down

BA2 7AY

United Kingdom

E-mail: j.hordern@bath.ac.uk.

The author is grateful to the University of Huddersfield for supporting this research project and to the reviewers for their comments on initial drafts of this paper.

\section{References}

Becher, T. and M. Kogan (1992), Process and Structure in Higher Education (eds.), Open University Press, Milton Keynes.

Bernstein, B. (1999), "Vertical and Horizontal Discourse: An Essay", British Journal of Sociology of Education, Vol. 20, No. 2, pp. 157-173.

Bleiklie, I. and M. Kogan (2007), “Organization and Governance of Universities”, Higher Education Policy, Vol. 20, No. 4, pp. 477-493.

Bolden, R. and G. Petrov (2008), Employer Engagement with Higher Education: A Literature Review, compiled for the South West Higher Level Skills Project on behalf of HERDA South West and HEFCE by the Centre for Leadership Studies, University of Exeter, http://centres.exeter.ac.uk/cls/documents/publications/399.pdf, accessed 7 September 2011.

Bone, D. (2008), "Internationalisation of HE: A Ten-Year View", DIUS HE Debate Series, www.timeshighereducation.co.uk/Journals/THE/THE/13_November_2008/attachments/I nternationalisation-Bone.pdf, accessed 20 November 2010. 
Brown, P. (2003), "The Opportunity Trap: Education and Employment in a Global Economy", European Education Research Journal, Vol. 2, No. 1, pp. 142-180, http:// centres.exeter.ac.uk/cls/documents/publications/399.pdf.

Brown, P., H. Lauder and D. Ashton (2010), The Global Auction: The Broken Promises of Education, Jobs and Rewards, Oxford University Press, New York.

Brennan, J. and B. Little (2006), Towards a strategy for workplace learning, Milton Keynes, Open University Centre for Higher Education Research and Information.

Burgess, T. and J. Pratt (1970), Policy and Practice: The Colleges of Advanced Technology, Allen Lane, London.

CBI, Universities UK and HEFCE (2008), Stepping Higher: Workforce Development through Employer-Higher Education Partnership: Literature Review, CBI, London.

Clark, B. (1983), The Higher Education System, University of California Press, Berkeley.

Craig, J. and A. Gunn (2010), "Higher Skills and the Knowledge Economy: The Challenge of Offshoring", Higher Education Management and Policy, Vol. 22, No. 3, pp. 1-17, OECD Publishing.

Davis, M. (2007), Skills in Context: A Briefing Prepared by the Centre for Enterprise, Futureskills Scotland, Glasgow.

Deem, R., S. Hillyard and M. Reed (2007), Knowledge, Higher Education, and the New Managerialism: The Changing Management of UK Universities, Oxford University Press, Oxford.

Delanty, G. (2001), Challenging Knowledge: The University in the Knowledge Society, Open University Press, Buckingham.

DIUS (Department for Innovation, Universities and Skills) (2007), World Class Skills: Implementing the Leitch Review of Skills in England, HMSO, London.

DIUS (2008a), Higher Education at Work: Higher Skills, Higher Value, HMSO, London.

DIUS (2008b), Innovation Nation: Executive Summary, HMSO, London, www.bis.gov.uk/ assets/biscore/corporate/migratedd/publications/i/innovation_nation_exec_summary.pdf, accessed 10 August 2009.

DiMaggio, P. and W. Powell (1983), “The Iron Cage Revisited: Institutional Isomorphism and Collective Rationality in Organizational Fields", American Sociological Review, Vol. 48, No. 2, pp. 147-60.

DiMaggio, P. and W. Powell (1991), "Introduction", in W. Powell and P. DiMaggio (eds.), The New Institutionalism in Organizational Analysis, University of Chicago Press, Chicago, pp. 1-38.

Eastwood, D. (2008), “Oral Evidence: Innovation, Universities, Science and Skills Select Committee inquiry", in After Leitch: Implementing Skills and Training Policies, Response to question 285, House of Commons, London, www.publications.parliament.uk/pa/cm200708/cmselect/cmdius/c505-iv/c50502.htm, accessed 7 March 2010.

Estermann, T., T. Nokkala and M. Steinel (2011), University Autonomy in Europe II: The Scorecard, European University Association, www.eua.be/Libraries/Publications/ University_Autonomy_in_Europe_II_-_The_Scorecard.sflb.ashx, accessed 6 January 2012.

Frean, A. (2008), “Cambridge University's Alison Richard condemns push for state pupils", The Times, 10 September, www.timesonline.co.uk/tol/life_and_style/education/ article4720330.ece, accessed 14 January 2010. 
Garnett, J. et al. (2008), "Developing the Structural Capital of Higher Education Institutions to Support Work-Based Learning Programmes”, in F. Tallantyre (ed.), Work-Based Learning. Workforce Development: Connections, Frameworks and Processes, The Higher Education Academy, York, pp. 18-30.

Gibbons, M. et al. (1994), The New Production of Knowledge: The Dynamics of Science and Research in Contemporary Societies, Sage, London.

Giroux, H. (2003), "Selling Out Higher Education", Policy Futures in Education, Vol. 1, No. 1, pp. 179-200.

Grubb, W.N. and M. Lazerson (2004), The Education Gospel: The Economic Power of Schooling, Harvard University Press, Cambridge.

HEA (Higher Education Academy) (2006), The UK Professional Standards Framework for Supporting Learning and Teaching in Higher Education, Higher Education Academy, York, www.heacademy.ac.uk/ourwork/supportingindividuals/professionalrecognition, accessed 17 May 2009.

HEA (2008), "Work-Based Learning. Workforce Development: Connections", Frameworks and Processes, Higher Education Academy, York.

HEFCE (Higher Education Funding Council for England) (2006), Circular Letter 2006/06, HEFCE, Bristol.

HEFCE (2008), "Higher Education $\square$ Business and Community Interaction Survey 2006-07", HEFCE, Bristol, www.hefce.ac.uk/pubs/hefce/2008/08_22, accessed 17 April 2009.

HEFCE (2009), Employer Engagement Funded Projects, www.hefce.ac.uk/econsoc/ employer/projects, accessed 7 January 2009.

HM Treasury (2006), Leitch Review of Skills: Prosperity For All in the Global Economy - World Class Skills, HM Treasury, London.

Innovation Universities Science and Skills (IUSS) Select Committee (2009), Re-skilling for recovery: After Leitch, Implementing Skills and Training Policies, House of Commons, London, www.publications.parliament.uk/pa/cm200809/cmselect/cmdius/ 365/365.pdf, accessed 10 January 2010.

Keep, E. (2008), “Skills and Economic and Social Justice”, SKOPE Issues Paper 16, SKOPE, Cardiff.

Kerr, C. (1990), “The American Mixture of Higher Education in Perspective: Four Dimensions", Higher Education, Vol. 19, No. 1, pp. 1-19.

Kerr, C. (2001), The Uses of the University (5th ed.), Harvard University Press, Cambridge.

Kingston University (2008), Strategic Plan 2008/9-2012/3, Kingston University website, www.kingston.ac.uk/aboutkingstonuniversity/howtheuniversityworks/universityplan/do cuments/strategic_plan.pdf, accessed 15 March 2011.

Kogan, M and S. Hanney (2000), Reforming Higher Education, Jessica Kingsley, London.

Kogan, M. and S. Marton (2006), “The State and Higher Education”, in M. Kogan et al. (eds.) Transforming Higher Education: A Comparative Study (2nd ed.), Springer, Dordrecht, pp. 69-83.

Larsen, I. and L. Langfeldt (2005), "Profiling Comprehensiveness? Strategy Formulations and Effects of Strategic Programmes at Traditional Universities", in Å. Gornitzka, M. Kogan and A. Amaral (eds.), Reform and Change in Higher Education: Analysing Policy Implementation, Springer, Dordrecht, pp. 343-362. 
March, J. and J. Olsen (1984), “The New Institutionalism: Organizational Factors in Political Life", American Political Science Review, Vol. 78, pp. 734-749.

Million (2008), Memorandum 36: Submission from Million+ (Memoranda of written evidence for the IUSS Select Committee inquiry: "After Leitch - Implementing Skills and Training Policies"), House of Commons, London, www.publications.parliament.uk/ pa/cm200708/cmselect/cmdius/memo/505/ucm01.pdf, accessed 10 May 2010.

McNay, I. (2005), "Higher Education Communities: Divided they Fail?", Perspectives: Policy and Practice in Higher Education, Vol. 9, No. 2, pp. 39-44.

Pratt, J. and T. Burgess (1974), Polytechnics: A Report, Pitman, London.

Pratt, J. (1997), The Polytechnic Experiment: 1965-1992, Open University Press, Buckingham.

Sastry, T. and B. Bekhradnia (2007), Higher Education, Skills and Employer Engagement, HEPI, Oxford, www.hepi.ac.uk/files/30HEskillsandemployerengagement summary.pdf, accessed 11 October 2008.

Scott, W. and J. Meyer (1991), "The Organization of Societal Sectors: Propositions and Early Evidence", in W.W. Powell and P.J. DiMaggio, (eds.), The New Institutionalism in Organizational Analysis, The University of Chicago Press, Chicago, pp. 108-140.

Shephard, J. (2008), “Cambridge Mission 'not social mobility”, The Guardian, 10 September, www.guardian.co.uk/education/2008/sep/10/accesstouniversity.highereducation, accessed 4 February 2010.

Stedward, G. (2003), "Education as Industrial Policy: New Labour's Marriage of the Social and the Economic", Policy and Politics, Vol. 31, No. 2, pp. 139-152.

Stensaker, B. and J. Norgard (2001), "Innovation and Isomorphism: A Case-study of University Identity Struggle 1969-1999”, Higher Education, Vol. 42, pp. 473-492.

Stevens, R. (2004), University to Uni: The Politics of Higher Education in England since 1944, Politico's, London.

Symes, C. and J. McIntyre (eds.) (2000), Working Knowledge: The New Vocationalism and Higher Education, SRHE/Open University Press, Buckingham.

Tapper, E. and B. Salter (1995), “The Changing Idea of University Autonomy”, Studies in Higher Education, Vol. 20, No. 1, pp. 59-71.

Tierney, W. (1988), “Organizational Culture in Higher Education: Defining the Essentials", The Journal of Higher Education, Vol. 59, No. 1, pp. 2-21.

Timlin, J., R. Eyres and P. Ward (2010), Supporting academic staff to facilitate workforce development provision, HEA, York, www.heacademy.ac.uk/assets/York/documents/ourwork/ employability/employerengagement/EEL_chapter6.pdf, accessed 10 August 2010.

UKCES (United Kingdom Commission on Employment and Skills) (2009), "Ambition 2020: World Class Skills and Jobs for the UK", www.ukces.org.uk/ publications-and-resources/browse-by-title/ambition-2020-world-class-skills-and-jobsfor-the-uk, accessed 4 December 2009.

Universities UK (2008a), Memorandum 46: Submission from Universities UK (Memoranda of written evidence for the IUSS Select Committee Enquiry: "After Leitch - Implementing Skills and Training Policies"), House of Commons, London, www.publications.parliament.uk/pa/cm200708/cmselect/cmdius/memo/505/ucm01.pdf, accessed 10 May 2010. 
Universities UK (2008b), Standing Together: Universities Helping Business Through the Downturn, UUK, London, www.universitiesuk.ac.uk/Publications/Pages/StandingTogether.aspx, accessed 10 January 2010.

Vickers, P. and B. Bekhradnia (2007), The Economic Costs and Benefits of International Students, Higher Education Policy Institute, Oxford, www.hepi.ac.uk/466-1304/TheEconomic-Costs-and-Benefits-of-International-Students.html, accessed 22 July 2008.

Voorhees R. and L. Harvey (eds.) (2005), Workforce Development and Higher Education: A Strategic Role for Institutional Research, New Directions for Institutional Research No. 128, Jossey-Bass, San Francisco.

Vught, F. (van) (2008), "Mission Diversity and Reputation in Higher Education”, Higher Education Policy, Vol. 21, pp. 151-174.

Watson, D. (2007), "The University and its Communities", Higher Education Management and Policy, Vol. 19, No. 2, pp. 21-29, OECD Publishing.

Wedgewood, M. (2008), "Higher Education for the Workforce: Barriers and Facilitators to Employer Engagement", Department of Innovation Universities and Skills, www.bis.gou.uk/assets/biscore/corporate/migratedD/publications/D/DIUS_RR_08_04, accessed 4 August 2011. 
